International Center for Public Policy

Working Paper 15-09

November 2015

Fiscal Decentralization and Decentralizing

Tax Administration: Different Questions,

Different Answers

Richard M. Bird 

International Center for Public Policy

Working Paper 15-09

\section{Fiscal Decentralization and Decentralizing Tax Administration: Different Questions, Different Answers}

Richard M. Bird

November 2015 


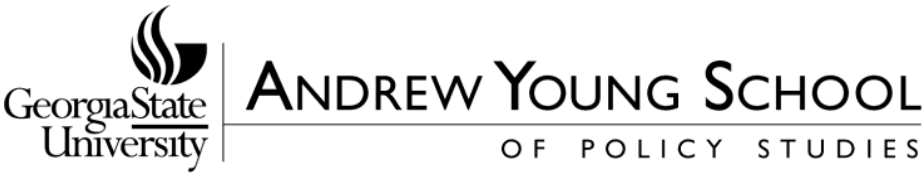

\section{International Center for Public Policy Andrew Young School of Policy Studies}

The Andrew Young School of Policy Studies was established at Georgia State University with the objective of promoting excellence in the design, implementation, and evaluation of public policy. In addition to two academic departments (economics and public administration), the Andrew Young School houses seven leading research centers and policy programs, including the International Center for Public Policy.

The mission of the International Center for Public Policy is to provide academic and professional training, applied research, and technical assistance in support of sound public policy and sustainable economic growth in developing and transitional economies.

The International Center for Public Policy at the Andrew Young School of Policy Studies is recognized worldwide for its efforts in support of economic and public policy reforms through technical assistance and training around the world. This reputation has been built serving a diverse client base, including the World Bank, the U.S. Agency for International Development (USAID), the United Nations Development Programme (UNDP), finance ministries, government organizations, legislative bodies and private sector institutions.

The success of the International Center for Public Policy reflects the breadth and depth of the in-house technical expertise that the International Center for Public Policy can draw upon. The Andrew Young School's faculty are leading experts in economics and public policy and have authored books, published in major academic and technical journals, and have extensive experience in designing and implementing technical assistance and training programs. Andrew Young School faculty have been active in policy reform in over 40 countries around the world. Our technical assistance strategy is not to merely provide technical prescriptions for policy reform, but to engage in a collaborative effort with the host government and donor agency to identify and analyze the issues at hand, arrive at policy solutions and implement reforms.

The International Center for Public Policy specializes in four broad policy areas:

- Fiscal policy, including tax reforms, public expenditure reviews, tax administration reform

- Fiscal decentralization, including fiscal decentralization reforms, design of intergovernmental transfer systems, urban government finance

- Budgeting and fiscal management, including local government budgeting, performancebased budgeting, capital budgeting, multi-year budgeting

- Economic analysis and revenue forecasting, including micro-simulation, time series forecasting,

For more information about our technical assistance activities and training programs, please visit our website at http://aysps.gsu.edu/isp/index.html or contact us by email at gbotello1@gsu.edu 


\title{
Fiscal Decentralization and Decentralizing Tax Administration: Different Questions, Different Answers
}

\author{
Richard M. Bird \\ Joseph L. Rotman School of Management \\ University of Toronto
}

November 2015

\begin{abstract}
The case for decentralizing taxes does not imply that these taxes need to be administered locally. Nor is it is necessarily constrained by the weakness of local tax administration. Tax decentralization and the decentralization of tax administration are related but separable decisions. As discussed in this paper, different countries have at different times have reached different conclusions about the appropriate way to mix and match these issues. No country may have it quite right when taking all the relevant factors into consideration, at least when viewed from outside. However, decisions on such matters are not made outside but inside specific countries, few involved in such decisions are likely to attach the same weights to all factors, and usually no one has the full story in mind when decisions are made. As with many questions of institutional design, there is no one size fits all correct answer to either the question of the extent to which taxes should be decentralized or the question of whether such taxes should also be administered in a decentralized fashion. However, thinking through these two distinct questions separately can be a useful step towards achieving better outcomes.
\end{abstract}

Key words: fiscal decentralization; tax administration; Canada; China; Germany; Spain

JEL Codes: H7, H83, P35, P43, O57 


\title{
Fiscal Decentralization and Decentralizing Tax Administration: Different Questions, Different Answers
}

\author{
Richard M. Bird ${ }^{1}$
}

\section{Introduction}

Three critical aspects of any government fiscal system are revenue policy - what taxes (and other charges) are imposed; revenue administration - how taxes are administered and collected; and revenue management -- how the revenue obtained is spent and who gets what. Most analytical attention has perhaps been focused on issues of tax policy, while most public attention has probably been paid to the endlessly controversial questions of who pays what and who gets what. In some key respects, however, the critical link between the decision about how to raise public sector revenue and how to spend it is tax administration -- the organization and management of the process of assessing, collecting and enforcing taxation (and other current revenue). ${ }^{2}$

One important aspect of tax administration that has received some attention recently is the extent to which tax administration should be decentralized. Should there be one central revenue administration or should every government in a country have its own revenue administration ? $^{3}$ Different countries have reached very different answers to this question. In Denmark, for example, central government and local government tax administrations were merged in 2005 and the unified administration was further restructured in 2013 when the regional structure was completely abolished (OECD 2015). However, Denmark is both a unitary country and an unusually unified one with relatively little evidence of significant regional or local differences in preferences. ${ }^{4}$ In contrast, in some federal countries, notably the United States and Switzerland, most governments at every level are responsible for administering most or all of their own taxes. In other developed federations, however, although state, regional and

\footnotetext{
${ }^{1}$ Professor Emeritus, Rotman School of Management, University of Toronto. Some of the material in Section 4 is drawn from a forthcoming joint work with Roy Bahl although I am solely responsible for its use here.

${ }^{2}$ The related but distinct questions of financing capital spending or, for that matter, deficits are not considered here, and non-tax current revenues such as fees and charges are also left aside. Slemrod and Gillitzer (2014) provide an analytical treatment of tax systems that pays close attention to tax administration, but they do not consider the decentralization question that is the focus of this paper.

${ }^{3}$ See Vehorn and Ahmad (1997), Mikesell (2007) and Martinez-Vazquez and Timofeev (2010) for excellent previous reviews. A related issue is the extent to which a central tax administration itself should operate in a decentralized fashion: as OECD (2015) discusses, a number of countries in recent years have undertaken large-scale rationalization of their territorial office networks, recognizing the greatly increased role of information technology and especially the internet in reaching and communicating with taxpayers and reducing substantially the number of local tax offices. However, this issue is not discussed here.

${ }^{4}$ Of course, as recently discussed by Lotz, Blom-Hansen, and Hede (2015), there remain some continuing tensions between central and local governments even in Denmark.
} 
local governments usually have their own tax administrations, some state taxes are often actually administered at the federal level and some local taxes largely determined at the state level. ${ }^{5}$

In Australia, for example, all the revenues of the Goods and Services Tax (GST), which is administered by the federal government, go to the state governments. However, because the GST is imposed by federal law at a uniform rate throughout the country, from most perspectives it is not really a state tax but rather a form of 'tax sharing' equivalent to an intergovernmental transfer distributed on the basis of estimated collections in each region (Bird and Smart 2010). On the other hand, in Canada, where the main regional revenues are income and sales taxes, the federal government currently administers nine (out of 10) provincial personal income taxes, as well as eight provincial corporate income taxes, and five provincial sales taxes. Nonetheless, since in all cases the provinces are responsible for setting the rates and, within some limits, can also alter the base of the tax, all these federally-administered taxes are essentially provincial taxes (Bird 2014). More unusually, one province in Canada (Quebec) administers not only its own sales tax but also the federal sales tax. Germany takes this much further, with the states being responsible for most aspects of administering federal taxes, as discussed further in Section 3 below.

In Latin America, some local taxes are administered at the national level in Argentina, Brazil, Chile, Dominican Republic, Guatemala, Nicaragua, Panama and Peru (CIAT 2012, Table 5). In Mexico, although the states and the Federal District (Mexico City) have ceded most tax authority to the central government, the agreements providing for tax coordination and administrative cooperation with the federal government empower the states to collect and audit federal taxes. In practice, however, the highly centralized State Tax Administration (SAT, Servicio de Administración Tributaria) seems to be in full charge (Velasco 2008). ${ }^{6}$ Even when states do collect taxes as with respect to a simplified tax on small business they appear to do a poor job, with widespread evasion (Fretes Cibils and Ter-Minassian 2015). ${ }^{7}$ To a considerable extent, however, this failure likely reflects the perverse incentives arising from the high level of dependence on poorly-designed federal transfers. ${ }^{8}$ In Argentina, where much the same happens, Piffano (2005) argues that the present system of tax sharing should be replaced by a combination of more coordinated and centralized administration of most important sub-national taxes

\footnotetext{
${ }^{5}$ Each country has its own governance structure and often its own terminology. In the US and Australia, the intermediate-level governments are states and lower-level (general) governments are local; in Canada, they are provinces and municipalities; in Switzerland, cantons and communes; and so on. For simplicity, however, we often refer here to intermediate (regional) governments as states or regions and to lower-level local governments (of which there are often several varieties and even levels) as local governments.

${ }^{6}$ Most of the transitional countries of central and eastern Europe also have a centrally-controlled tax administration, with regional governments sometimes have no tax administration role at all although local governments often collect some revenues, especially property taxes (Hőgye (2000) provides an early overview; for a recent examination of the situation in Poland, see Swianiewicz and Lokomsa (2015).

${ }^{7}$ For a more positive view of a somewhat similar system in Ethiopia, which is argued to increase both the fairness of taxation and state legitimacy, see Joshi, Prichard and Heady (2014).

${ }^{8}$ As Weingast (2009) argues, local political autonomy in terms of elections and making spending decisions may, in the presence of fiscal dependence, all too easily become a means of political control rather than citizen choice. Requiring (and enabling) sub-national governments to be responsible for raising their own revenues is thus one important way to make political autonomy real. However, transfers must also be properly designed (Bird and Smart 2002).
} 
(for example, establishing a uniform national cadastre and automobile register) and giving provinces more autonomy in setting tax rates (as in Canada).

As a final example, local taxes are sometimes administered at least in part by the next higher level of government in many countries. In both Australia and Canada, for example, the main local tax is the property tax, but the base of that tax, the assessed value of real property, is often set by the state government. In the United States, local sales taxes are administered by 38 of the 45 states which have sales taxes of their own (Drenkard 2014). In contrast, in Sweden and other unitary Nordic countries, although the main local tax is the income tax and localities usually have some power to vary the tax rate, the tax is administered solely by the central revenue administration.

The extent to which taxes for which one level of government is formally politically responsible are administered by other governments does not seem related in any fixed way either to the formal constitutional structure of a country or its level of development. What countries do with respect to decentralizing tax administration -- though no doubt often reflecting the inertia of past choices made in response to changing political institutions, technology, and economic conditions -- appears to be largely up to them. Before discussing further the question of how decentralized taxes are or should be administered, however, Section 2 first touches briefly on the surprisingly complex question of how one may characterize a tax as being decentralized in the first place. Section 3 then provides a more detailed account of how decentralized taxes are administered in practice in several very different countries. Section 4 discusses the main key arguments for and against decentralizing the administration of decentralized taxes. Section 5 concludes.

\section{What is a 'Decentralized' Tax?}

Is a decentralized tax: (1) One where regional or local governments have the power to decide whether to impose it or not? (2) One where they determine the tax base? (3) One where they set the tax rate? (4) One where they determine the liability of particular taxpayers? (5) One where they collect and enforce the tax? (6) One where they receive the revenue? (7) Or one where certain combinations of the above conditions exist? As Blochinger and King (2006) discuss in detail, there are many possible ways to 'mix and match' these characteristics. They distinguish 13 different possibilities in the 30 OECD countries, taking into account only the degree of discretion over tax policy decisions and not such questions as whether and how more than one level of government controls some aspects of administration.

Whether a government controls its own revenue sources in a meaningful way is critical no matter how one measures control. As Martinez-Vazquez, McLure and Vaillancourt $(2006,21)$ note, "if fiscal decentralization is to be a reality, subnational governments must control their own sources of revenue. Subnational governments that lack independent sources of revenue can never truly enjoy fiscal autonomy, because they may be-and probably are-under the financial thumb of the central government." Simply having a constitutionally guaranteed share of central revenues may seem to guarantee autonomy in this sense. But spending autonomy financed from on high is much less likely to be spent as local citizens would wish than if they had to find the funds in their own pockets. History and 
theory suggest strongly that for local governments to be responsibly autonomous they must be responsible to local citizens for how they raise as well as spend revenues. Democratic local elections and transparent - and preferably comparative -- reporting to citizens about local spending patterns are two obvious ways to move towards this goal (Bird 2000). But even the most democratic local government is likely to spend more responsibly if it also bears some responsibility for raising revenue by imposing taxes on residents in a visible and accountable way. ${ }^{9}$

The single most important factor ensuring that sub-national governments are accountable to their citizens is probably to make them clearly and visibly responsible for determining tax rates. The tax rate is for most people the most visible and understandable characteristic of any tax (McLure 2000). The more power regional and local governments have in terms of collecting revenue - choosing which taxes to impose, how the tax base is defined, and actually assessing and collecting the tax - the greater their fiscal autonomy. But without the ability to establish and alter tax rates, even if only within some limits, the transparency and accountability of the local revenue system is likely to fall short of what is needed to support the economic case for fiscal decentralization (Oates 1972). Provided regional and local governments can meaningfully establish tax rates, it does not seem necessary for them to administer taxes themselves in order to operate effectively and efficiently. There may be good reasons why some sub-national taxes should be administered locally because it is efficient to do so and because doing so clearly adds to local autonomy which may be considered desirable in itself. But fiscal and administrative decentralization, while related, are distinct: one may have much of one with little or none of the other, as shown by the case studies next discussed.

\section{Tales from Four Countries -- All Decentralized, and All Different}

Four brief case studies of fiscal and administrative decentralization are set out in this section: Canada, China, Germany, and Spain. A few basic parameters with respect to the tax administration structures in these countries (plus the United States, for comparative purposes) are set out in Table 1. The main conclusion suggested by this table is simply that each country is very different in some respects from the others both in how centralized its tax administration is and in terms of costs of collection and the citizen/staff ratio. ${ }^{10}$

To provide a base case that may be familiar to some, data for the United States are also shown in Table 1. Although the federal tax administration in the U.S. appears in relative terms to be relatively efficient and decentralized - only 4.7 percent of employees at $\mathrm{HQ}$, and costs ( 0.47 percent) are relatively low and the citizen/staff ratio $(3,635)$ relatively high -- these factors of course reflect in part the fact that there is, uniquely, no major federal indirect tax in the U.S. The U.S. as a whole, with 536,312 public employees at

\footnotetext{
${ }^{9}$ This is one of the main tenets of the so-called 'second generation' theories of fiscal federalism (Weingast 2009).

${ }^{10}$ While numbers are provided for these two ratios where available, as OECD (2015) explains, extreme care is needed when comparing these numbers owing to the very different situations found in different countries.
} 
the federal, state and local levels concerned with financial administration in $2013,{ }^{11}$ seems comparable in scale only to that of China. However, unlike China (or any of the other countries discussed here), there is effectively no central direction or coordination of the very different tax systems and tax administrations found at the state and local level in the United States. Those who want to see what a truly decentralized tax administrative system looks like need look no further.

Table 1. Setting the Stage: The Structure of Tax Administration

\begin{tabular}{|l|l|l|l|l|l|}
\hline & Canada & China & Germany & Spain & United States \\
\hline Number of employees & 38,172 & 756,000 & 110,494 & 26,231 & 86,977 \\
\hline Number at HQ & 8,897 & 800 & 1,236 & 3,416 & 4,073 \\
(percent of total) & $(23.3)$ & $(0.1)$ & $(1.1)$ & $(13.0)$ & $(4.7)$ \\
\hline Number of HQ offices & 1 & 1 & 17 & 1 & 1 \\
\hline Number of regional offices & 5 & 71 & 12 & 56 & 139 \\
\hline Number of local offices & 39 & 6,667 & 546 & 227 & 119 \\
\hline Citizens/FTE tax staff & 921 & n.a & 743 & 2,081 & 3,635 \\
\hline Administrative cost/net revenue collections & 1.16 & n.a. & 1.35 & 0.67 & 0.47 \\
\hline
\end{tabular}

Notes: Canada - number of employees excludes 1,359 dealing with non-tax functions; China regional offices include provincial offices and those in municipalities directly under central government, while local offices include those at municipal level and county and district offices directed by provincial offices; Germany - HQ include 16 Länder administrations. There are also 34 call centres, 28 of which are located in one state (Hesse); cost ratio excludes social security contributions and excises; Spain - includes 17 regional offices, 39 provincial offices, 192 local tax offices and 31 customs and excise local offices; costs include customs but exclude social security contributions; United States - no major federal indirect tax; the regional-local breakdown is approximate; cost ratio differs from official IRS figures, which are based on gross rather than net collection.

Source: OECD (2015), Tables 2.3, 2.4, 5.4, 5.6.

\section{Germany}

In contrast, Germany provides an example of what may perhaps be called a highly centralized decentralized system. Many taxes in Germany are constitutionally assigned to one level of government federal, state (länder), or local (communities). However, most important taxes, accounting for about

\footnotetext{
${ }^{11}$ Census of Employees at Federal, State and Local Levels, March 2013: http://factfinder.census.gov/faces/tableservices/isf/pages/productview.xhtml?src=bkmk (accessed 4 November 2015).
} 
three-quarters of total revenue, are 'common' and are shared between two or all three levels of government in specific percentage shares. Such tax-sharing arrangements are not uncommon in federal countries. What is considerably less common, however, is the way in which taxes are administered in Germany. The federal tax administration administers only customs duties and some federally regulated excises (including the beer duty although all the yield of this tax goes to the states). ${ }^{12}$ All other taxes are administered by the states, although they often delegate the administration of such specifically local taxes as the real property tax to local governments. ${ }^{13}$ State tax administration offices are thus both federal and state offices, with the federal government assuming the costs related to administering federal taxes.

Not only do German states administer almost all taxes, they can also decide how to do so. The main rule governing state administration is simply the basic constitutional rule that taxes must be administered uniformly (apart from some very small differences in local taxes in different communities). In most cases, there are regional tax offices that house both federal and state tax administrations and have a common president who is partly a federal and partly a state official. However, in Bavaria the state tax department is completely separated from the federal administration, and in other states there are sometimes specialized tax offices and no or more than one regional office. States can finance tax administration how and to the extent they wish and may also choose the extent to which and how they adopt new administrative technology such as specialized software. ${ }^{14}$ On the other hand, all tax rates are uniformly established at the national level. Moreover, the training of tax officers is also specified by national law and states are required establish training institutions -- although it is left to them to decide how to do this. Finally, as is true for all public servants in Germany, the basic wages of tax officers (though not necessarily their hours or bonuses) are set at the national level and are uniform throughout the country.

The German system is thus unique. On one hand, the states have no autonomy in setting tax rates and only limited control over tax officials. On the other, they have complete autonomy in deciding how to organize and administer both state and most important shared taxes (e.g. with respect to auditing efforts). ${ }^{15}$ Furthermore, there is no formal central authority to coordinate state tax administrations, although a complex network of boards, committees and work groups (e.g. to assess the performance of local tax offices) exists, with different states participating to different extents in coordinating different activities in various respects. As one would expect, studies suggest that the results of this awkward mix

\footnotetext{
${ }^{12}$ The federal administration is also responsible for administering any levies imposed on behalf of the European Union.

${ }^{13}$ Interestingly, however, the state administrations determine the assessed value of real property which serves as the base for both the local property tax and the federal inheritance tax. As Farber, Salm, and Hengswerth (2015) show, there is considerable dissatisfaction at all levels of government with the present state of property valuation in Germany but no consensus on how to reform the system. Assigning the assessment task to a higher-level government is common in many countries in which property taxes are essentially local (Bird and Slack 2004). ${ }^{14}$ Ulbricht (2008) describes the uneven and non-uniform way in which information technology was introduced at the state level.

${ }^{15}$ Ulbricht $(2008,206)$ refers to the differing audit structures in different states as producing problems similar to those arising in the EU as whole owing to lack of any central VAT audit system (Cnossen 2010).
} 
of responsibilities for different aspects of taxation between the national and state levels are far from uniform across states (Baretti, Huber and Lichtblau 2002).

Increased tax evasion and increased compliance costs have been blamed on this decentralized approach to tax administration. In addition, the evidence suggests that state tax administrations have responded to the incentives created by the equalization system by adjusting administrative efforts in such a way as to align the effective tax rates imposed on their residents to match the share of the marginal tax revenue that accrues to the states. The factors determining marginal tax back rates (MTBRs) - the share of the revenue collected that accrues to the state after equalization -- are exogenous to the state. Hence, although tax rates are uniform across states, variations in effective tax rates may arise because of variation in enforcement effort (e.g. the number and effectiveness of audits). States like North RhineWestphalia that are consistently net contributors to equalization have high marginal tax back rates (MBTRs) and hence lower incentives to enforce the tax law than states like Saarland that are consistent net recipients with low MBTRs (Bönke, Jochimsen and Schröder 2013).

Despite such problems, the unique German tax administration system has proven resistant to change for several reasons. Not only is it well-entrenched and popular with the states but it is considered to be more democratically responsive and accountable than a more centralized administration because states have to collect their own revenue rather than simply depend on tax shares transferred from a centralized collection system. However, as just mentioned, the strength of this last argument is clearly weakened by the offsetting effects of the particular equalization system in place in Germany which explicitly discourages tax efforts in richer states. ${ }^{16}$

\section{China}

Perhaps surprisingly, the country in which tax administration comes closest to the German model is probably China, in which an astonishingly small central tax office sets both policy and administrative guidelines but all taxes for all levels of government are actually collected by a vast network of regional (provincial) and local tax offices. Unlike Germany, Canada, Spain, or the United States, China is an explicitly unitary country, with four formal levels of government - central, provincial (as well five large 'special municipalities' which are for fiscal purposes treated much like provinces --like Hamburg and Bremen in Germany), county, and township. ${ }^{17}$

Until 1994 there was essentially no central tax administration in China. All taxes were collected by local tax offices, which collected both central taxes and taxes shared with the provinces as well as local taxes. However, with China's economic liberalization beginning in the 1980s the central government essentially lost control over the tax system, and both total tax revenues and the share of those revenues going to

\footnotetext{
${ }^{16}$ Any equalization system affects taxation in recipient states (Smart 1998); the German system explicitly affects tax efforts in donor states also.

${ }^{17}$ In addition, there are several hundred thousand rural villages, which - uniquely in China - actually have elected officials but also - uniquely among Chinese government units - have no formal taxing power. For a brief description of some aspects of village finance, see Bird et al. (2011).
} 
the central government declined sharply by the early 1990s (Wong and Bird 2008). The 1994 reform thus dramatically centralized taxation, including establishing a national tax administration for the first time and removing customs duties, value-added tax (VAT), and excises as well as the income tax on central enterprises from the control of Local Tax Bureaus (LTBs) and giving them to new State Tax Bureaus (STBs) which were organized in a hierarchy of provincial, prefectural/municipal and county tax offices under the central State Administration of Taxes (SAT). All organizational and human resource decisions at each level are under control of the next higher level, with SAT on top of the whole system. SAT also has some influence over the Local Tax Bureaus although they are predominately under the control of the provincial governments.

Despite this apparently centrally-controlled structure, many aspects of tax administration remain under regional control to varying extents. For example, provincial governments have some discretion over such items as VAT thresholds and various income tax reliefs as well as over local business and land taxes. More generally, as Cui $(2011,472)$ notes - and both Spanish and German experience also suggest “...whoever controls tax collection - a centrally- or locally-responsible tax office - partially determines the extent to which local governments control the actual implementation of tax policy...even in the absence of tax legislative power." Even though the relative recentralization of the tax system after the 1994 reform succeeded in increasing both tax revenue and the central share of tax revenue, the system as it actually operates continues to depend heavily on the exercise of administrative discretion at the local level. One perhaps surprising result appears to be that the central government has so little reliable information about taxpayer operations that few audits are carried out, with much greater reliance being placed on such arbitrary rules as limiting VAT credits and generally focusing enforcement efforts on relatively compliant and easy to monitor sectors (Cui 2015).

Moreover, although STBs, part of the central government administration, are responsible for administering central taxes, even the lowest level of the STB hierarchy - the county - encompasses such a large area that in practice for many taxpayers the real face of the tax administration is an 'outpost' office covering a much smaller territory, staffed by lower-level (and less well-paid) personnel, who are sometimes partly funded by local governments (Cui 2015). To a large extent the real work of tax administration in China is thus carried out by officials at the very bottom of the enormous state bureaucratic machine who may not be well qualified and are often responsive to local as well as central influences. It is not surprising that the combination of this administrative structure and the considerable degree of local discretion in administering both central and local taxes arguably explains the relative underdevelopment of tax litigation and the tax legal profession in China: as Cui $(2015,37)$ says, “...the law ceases to be relevant beyond the boundaries of specific tax administrator's knowledge about the law."

Many years ago Casanegra (1990) noted that in developing countries tax administration often was tax policy in the sense of determining whether and how policy intentions were realized. The decentralized way in which Chinese taxes are administered perhaps pushes this point so far that tax administration may become not just policy but de facto law. If what low-level officials at the taxpayer interface (whether in an STB outpost or an LTB office) decide should be done differs from what the law or SAT may seem to indicate should be done in the circumstances of the case, the lowest decision almost 
always prevails. It is hard to have a more decentralized tax administration than this. Whether the outcomes of such a system are likely to be efficient, equitable, accountable, or desirable is of course another question.

\section{Spain}

Spain, like China, is not a federation. However, it is also decidedly not a unitary state. In fiscal terms, it is a uniquely asymmetrical decentralized country which is still working out precisely how and to what extent the apparently conflicting desire for increased state autonomy and national unity can best be accommodated. Perhaps the closest parallels are the case of Quebec in Canada (discussed below) and Belgium and perhaps in the near future the increasingly less United Kingdom, although the fiscal parameters of the last two cases are not further discussed here. ${ }^{18}$

Any discussion of tax administration in Spain must begin by noting the unique characteristics of the fiscal regime applying in the two foral states (technically, "autonomous communities"), Navarre and the Basque Country. In these regions, essentially for historical reasons, all tax revenues are and always have been collected at the state level - or, more precisely in the case of the Basque Country, by the three provinces that make up that state. ${ }^{19}$ These regions have almost complete fiscal autonomy over personal and corporate income taxes as well as administrative control over VAT and excise duties: in effect, they administer all central taxes other than import duties and payroll taxes. However, the central tax agency (AEAT, Agencia Estatal de Administración Tributaria) is in charge of managing corporate and VAT returns for companies that by law must file national returns although they are fiscally domiciled in the Basque Country (Esteller Moré 2008). The foral regions benefit from but do not explicitly contribute to the equalization transfer system. ${ }^{20}$ They can choose to exert the same tax effort as other regions and end up with higher spending or lower their tax effort and end up with the same level of spending. For the most part, they appear to have chosen to reduce taxes in order to attract investment -- at no cost to their taxpayers (López Laborda and Monasterio Escudero 2007). ${ }^{21}$

Apart from the long history of the foral system, however, tax decentralization in Spain is a relatively new phenomenon. The Spanish tax system has undergone substantial changes since it was launched in its present form in 1977, and is unlikely as yet to have reached its final development. ${ }^{22}$ Although new taxes on income and wealth were introduced in 1977, the administration remained essentially centralized

\footnotetext{
${ }^{18}$ On Belgium, see Bayenet and de Bruycker (2007); Belgium has recently given regions considerable autonomy over some taxes, including the right to administer them, and some regions have chosen to do so (OECE 2015). A useful recent overview of the situation in Scotland may be found in Bell, Eiser and Beckman (2014).

${ }^{19}$ The state tax agency in the Basque Country is principally concerned with coordinating the work of the three provincial administrations (Esteller Moré 2008)

${ }^{20}$ The Basque Country (and Navarre) pay a negotiated amount to the central government (varying from year but usually close to 10 percent of the revenue they collect) to cover a few other central outlays such as defence and foreign affairs (Gray 2015).

${ }^{21}$ For a critical view of the fiscal asymmetry resulting from the foral system, see Garcia-Milà and McGuire (2007).

${ }^{22}$ For a review of the first 30 years, see Martinez-Vazquez and Sanz-Sanz (2007); a more recent appraisal of fiscal federalism in Spain may be found in Ruiz Almendral (2012).
} 
until the mid-1980s when the VAT was introduced and tax administration was substantially decentralized (Onrubia 2008). New regional offices of the central administration were created in each state, with the old provincial (district) offices being subordinated to them, and over 200 new local tax offices were created and charged with supervision and auditing of small business taxpayers. The new state administrations were put in charge of taxes on wealth. Despite substantial early efforts to improve the information technology system underlying tax administration (Moya and Santiago 1992), problems in coordinating this fragmented administrative structure appear to be one factor resulting in regional differences in the effectiveness of enforcement. ${ }^{23}$

This question became more important in the mid-1990s when the states had not only established their own tax administration departments but were also given additional taxing powers (e.g. property transfer tax and vehicle registration tax) as well as significant shares in income tax and VAT, although the latter continue to be administered by the central tax agency (AEAT), which was established in its present form in $1997 .{ }^{24}$ State tax agencies had some representatives on the board of directors of AEAT and a number of formal intergovernmental committees were established to improve interagency coordination. On the whole, however, the central agency dominated tax administration although how effective this structure was in the absence of strong incentives for regions to cooperate was not clear (Onrubia 2008). Since there is obviously considerable overlap between e.g. the net wealth tax administered by the states and the income tax administered by the centre as well as potential for regional competition in the form of differential enforcement efforts, some degree of cooperation at least in the form of information exchange would seem to be called for. ${ }^{25}$ However, although it may emerge over time, as yet it is not clear that the necessary degree of reciprocity (in terms of the extent to which the misreported revenues resulting from the lack of such exchange exceed the cost for most regions) exists to provide sufficient incentive to make such exchanges work (Durán-Cabré, Esteller-Moré and Salvadori 2015). ${ }^{26}$

Although some autonomous communities (states), in particular Catalonia, have continued to press for more fiscal autonomy, ${ }^{27}$ for the most part their main concern has been simply to obtain increased financial resources. First, they obtained some power over personal income tax and some other 'ceded' taxes; next, they sought more control over taxes such as VAT and corporation tax as well as a more

\footnotetext{
${ }^{23}$ Wealth tax returns are designed by the central tax agency and filed with the income tax return, although the process of controlling and monitoring returns and verifying data is carried on by the states. The central agency can also audit if it so chooses (Esteller Moré 2008).

${ }^{24}$ Although state administration of the newly transferred taxes was formally subject to annual audit by the central Ministry of Finance, Onrubia $(2008,510)$ notes that this is "...a formal requirement with hardly any implications for...the regional tax administrations." Esteller Moré (2008) outlines how revenues from shared taxes are allocated and transferred to the different states and notes that --as in Canada (Bird and Gendron 2010) --timing and adjustment issues have occasionally led to disputes.

${ }^{25}$ For evidence of such competition in Spain see Durán-Cabré, Esteller-Moré and Salvadori (2012): as they note, one benefit of giving states more formal legal authority over tax rates is to make such competition more transparent than when it is opaquely hidden in differential enforcement efforts (as in the German case).

${ }^{26}$ The cited study notes that some regions were particularly 'sluggish' in responding to information requests. Although the issue has not been explored, perhaps 'sluggishness' may reflect opportunistic challenges (Bednar 2009) to federal influence.

${ }^{27}$ For an early example, see Castells (2001); the author later became Catalonia's Minister of Finance.
} 
important role in tax administration. However, as in Germany, Spain's intergovernmental fiscal transfer system is so designed that states have little or no incentive to enforce effectively even the taxes they are supposed to regulate (Ruiz Almendral 2012). In this and other respects, the "work in progress" that is fiscal federalism in Spain does not as yet appear to have reached an equilibrium that will prove sustainable over time. In all likelihood, as in the quite different case of China, there will be yet more changes to the level and nature of tax administration in the future. ${ }^{28}$

\section{Canada}

Canada is, by most standards, one of the most fiscally decentralized countries in the world. However, its tax administration is substantially less decentralized than that in Germany, Spain, China, or the United States. Unlike many federations (e.g. India), there is no effective separation of revenue sources between federal and provincial governments. ${ }^{29}$ Moreover, there are no formal 'tax sharing' arrangements - like those in Germany, for example - that divide the revenues of particular taxes between levels of government. Instead, over a long history and especially over the last 50 years, an interestingly asymmetric administrative structure (somewhat like that in Spain) has been developed. The allocation of profits for corporate tax purposes has often given rise to controversy, and some specific rules exist for certain industries such as banks and pipeline companies, but all provinces, including those with independent income taxes, have adopted similar rules - a process that took place over decades of discussion and negotiation (Smith 1998) - and various federal and provincial working groups exist to deal with differential interpretations that might result in double taxation or alter the distribution of revenues in unacceptable ways (Berg-Dick et al., 2008).

One province, Quebec, administers its own personal and corporate income taxes as well as its sales tax; in addition, (as the German states do for almost all central taxes) it administers the federal value-added $\operatorname{tax}$ (Goods and Services Tax, GST) within its borders. The province is reimbursed by the federal government for the costs of administering the federal tax. Another province (Alberta) administers its own corporate income tax, and three provinces (British Columbia, Manitoba, and Saskatchewan) administer their own retail sales taxes. On the other hand, the federal tax administration, the Canada Revenue Agency (CRA), administers provincial personal income taxes in nine provinces, provincial corporate taxes in eight provinces, and provincial general sales taxes in five provinces. ${ }^{30}$ These federallyadministered provincial taxes are, in accordance with explicit agreements made with each province,

\footnotetext{
${ }^{28}$ Esteller Moré (2008) discusses several possible directions for reform and suggests that perhaps the best solution might be a formal consortium arrangement, with each level of government being equally represented on the governing body of AEAT, although he expresses some concern about the extent to which such arrangements (originally proposed by Catalonia) may result in an undesirable degree of tax diversity.

${ }^{29}$ The constitution appears to establish such a separation, with provinces being limited only to 'direct' taxes. However, over the years judicial interpretation enabled provinces to levy important general sales taxes as well as almost any other tax they care to impose (Alarie and Bird 2011). On the other hand, provinces maintain strict and strong control over municipal finances, with the result that the only significant local tax is the real property tax and the province usually in effect controls that tax also (as discussed, for example, in Bird, Slack and Tassonyi 2012).

${ }^{30}$ Alberta, like the three northern territories (Northwest Territories, Nunavut, and Yukon) has no sales tax.
} 
essentially similar in terms of their base to the corresponding federal taxes (as are the similar taxes administered independently by Quebec). All provinces can and do vary the base in certain respects (in the case of income taxes only by credits, however) and can also determine tax rates.

CRA is clearly an agency of the central government, reporting to a federal cabinet minister. However, 11 of the 15 members of CRA's Board of Management, which is appointed by the federal government, are nominated by the provinces (and territories), although all come from the private sector, with the exception of the federally-appointed Commissioner who heads the agency and is accountable both to the federal Minister of Revenue for administration of the legislation and to the Board for other administrative purposes (e.g. staffing and organizational issues). The CRA is subject to value-for-money audits by the federal Auditor General. That the provinces find this system acceptable is indicated both by the fact that, in 2009, Ontario turned over the administration of its corporate income tax to the CRA and that six provinces have in the last decade chosen to replace their general retail sales taxes by a federally-administered provincial value-added tax, which is administered jointly with the federal GST under the name of the harmonized sales tax (HST). ${ }^{31}$ The CRA administers these provincial taxes free of cost to the province provided its tax base is essentially identical to that of the corresponding federal tax. Each province has a separate tax administration agreement with the CRA which leaves them free to deviate to a limited extent from the federal tax structure e.g. by offering credits under the income tax and zero-rating specific activities under the sales tax. Provinces may also impose whatever rates they choose for income tax purposes: until 2015, for example, Alberta imposed only a flat-rate personal income tax, while Ontario imposed an additional surtax on higher incomes (and some corporations) in $2014 .^{32}$

In the case of the sales tax, the federal government will administer provincial-specific provisions for free provided that no more than five percent of the base is affected in total; it may also agree to administer additional specific deviations on a cost-reimbursable basis. ${ }^{33}$ Two provinces, Ontario and Quebec (the latter of which is not in the HST system although its tax base is essentially the same), have even been permitted to refrain from crediting some taxes on capital expenditures when made by large companies, although this deviation is permitted for only a limited period of time. Despite these differences in tax base between the federal and provincial taxes, as well as between the different provincial taxes, there

\footnotetext{
${ }^{31}$ At present, only five provinces have such a tax, because British Columbia withdrew from the agreement in 2013 following a referendum in which a majority favoured returning to the retail sales tax. The full story of Canada's gradual (and still incomplete) move towards an integrated federal-provincial value-added tax is told in Bird (2014).

${ }^{32}$ As Bird and Vaillancourt (2006) discuss, under the initial tax collection agreements participating provinces were able only to impose a single surtax rate on the federal income tax. This 'tax-on-tax' system was replaced in 2000 by a 'tax-on-income' approach allowing provinces to impose whatever tax rates they wanted without having to accept the progressivity set by the federal schedule (Canada, 2000).

${ }^{33}$ CRA administers well over a hundred separate programs for the provinces and territories. It also administers a number of income and sales taxes for various First Nations (aboriginal reserves), although this complex area is not further explored here (Nault 2006). In the 2013-14 fiscal year, CRA collected \$305 billion in taxes (excluding \$42 billion in pension contributions). About 31 percent of the taxes collected were provincial taxes: $\$ 55$ billion in personal income tax, \$13 billion in corporate income tax, and \$27 billion as the provincial share of the HST (Canada Revenue Agency 2014). A small amount of provincial sales (and excise) taxes are also collected at the border by the Canada Border Security Agency (CBSA), which also has explicit agreements with most provinces.
} 
have been no reported difficulties in administration and no serious problems with evasion with respect to cross-border sales, largely because the GST/HST system is operated in effect like an integrated national tax, with the allocation of revenues to the participating provinces being made in accordance with the estimated distribution of taxable base as determined by a federal-provincial working group. ${ }^{34}$

Canada's longest-serving Prime Minister (W.L.M. King) once dealt with one of the country's longest-lived political debates -- between Francophones, who mostly did not support military conscription, and Anglophones, who mostly did -- by saying at one point during the Second World War that he supported "conscription if necessary, but not necessarily conscription." Along somewhat similar lines, Canada's tax administration may be said to be centralized if necessary, but not necessarily centralized: most provincial taxes are now administered centrally but only with the support and agreement of the provinces; moreover, the taxes administered are clearly provincial and differ to varying extents from the corresponding federal taxes and from those in other provinces. These arrangements, though seldom the subject of public discussion, are almost constantly under review at both levels of government and are implemented in accordance with contractually agreed arrangements --- arrangements drafted largely by federal officials but with significant provincial input and with disagreements in interpretation being resolved by joint discussions. The setup as a whole is not that easy either to explain or understand. To date, however, much like the country itself (Bird and Vaillancourt 2006) it has not only managed to survive but also to accommodate substantially changing circumstances over time and across regions.

\section{The Case For and Against Decentralizing Tax Administration}

Traditionally, an important criterion in assigning taxes in the first place is whether the government to which they are assigned can feasibly administer them. Indeed, this seems to be the main reason why property taxes are so often assigned to local governments in most countries. This consideration seems likely to be especially important in the many developing countries in which tax administration has long been weak. Unfortunately, one argument cannot decide the issue. The property tax, for instance, is in some ways surprisingly difficult to administer well (Slack and Bird 2014). Concern with administrative feasibility does not outweigh other important considerations in choosing good regional and local taxes such as efficiency, equity, acceptability, and accountability.

The introduction of modern tax technology has in many ways made centralization less costly, as evidenced by the almost world-wide tendency of central administrations to reduce the number of local tax offices (OECD 2015). On the other hand, the continued attention being paid in many countries to the case for decentralizing many public sector activities (Faguet and Pöschl 2015), like the 'secondgeneration' theoretical arguments suggesting that decentralized governments need to be fiscally autonomous to some extent in order to deliver services effectively (see Section 2 above) point in the other direction when it comes to the administration of regional and local taxes. There is no one-size-fitsall solution to this question (Ambrosio and Bordignon 2015). Each country must weigh conflicting

\footnotetext{
${ }^{34}$ For a detailed discussion of how this system works, see Bird and Gendron (2010).
} 
arguments, some implying that administration should be centralized and others that it should be decentralized. Often, whether the balance is struck one way or another depends on institutional and empirical factors that can be dealt only in the specific context where the issue must be decided.

As Section 3 shows, how sub-national taxes should be administered remains an open question even in long-established developed countries. One author (Dillinger 1991) suggested some years ago that the choice was between incompetence (because local administrations are likely to be less capable) and indifference (because central administrations are not likely to pay much attention to local concerns). This view is too simple. It is true that when administration has been turned over to local governments, the results have not always been good. ${ }^{35}$ Although high costs may sometimes reflect the badly-designed taxes that local governments are supposed to administer, they may equally be the result of poor administrative capacity, incompetence, and corruption at the local level. But even when tax policies are well-designed and administrations at both levels of government are well-run, as in Canada, the evidence that a single administration is more cost-effective than multiple administrations is strong. ${ }^{36}$

One important reason for centralizing tax administration is to reduce the costs of taxation.

Decentralizing administration increases collection and compliance costs because fixed costs are associated with collecting any tax, so that the more jurisdictions that collect the greater the total cost incurred. Evasion and avoidance may also increase with decentralization for taxes where the tax base is mobile or straddles more than one jurisdiction. The administrative, compliance, and efficiency (and inequity) costs associated with taxes may all be reduced by limiting the number of agencies engaged in tax administration. The economies of scale and scope associated with the information systems on which modern tax systems are increasingly dependent (Bird and Zolt 2008) may be achieved through more effective and coordinated use of specialized staff in a more centralized administrative structure. Compliance costs are reduced when taxpayers submit fewer returns, interact with fewer officials and offices, and deal with a more uniform and harmonized administrative structure. Administrative costs are reduced when it is simpler to communicate laws and regulations to officials and establish exchanges of information and coordination of action without complex interagency or interjurisdictional negotiations. A more uniform and better coordinated administrative system should also be able to provide more equal procedural treatment to all taxpayers and to cope more effectively with the complications arising from cross-border transactions as well as with evasion in general. It may also be less susceptible to political interference and corruption.

On the other hand, as experience in numerous countries around the world has shown, sub-national governments may be correct to worry that the central government will be less enthusiastic about

\footnotetext{
${ }^{35}$ In Indonesia, for example, local administrative costs eat up over 50 percent of the revenue collected (Lewis 2006); in Argentina, administrative costs at the provincial level vary from 1.1 percent - less than the 2 percent at the national level - to over 10 percent (Fretes Cibils and Ter-Minassian 2015).

${ }^{36}$ Single administration of federal and provincial corporate income taxes was estimated to reduce compliance costs by 1.3 percent of the amount collected (Plamondon and Zussman 1998). When Ontario shifted administration of its CIT and later its sales taxes to the CRA, the provincial government noted that substantial reductions in administrative costs were an important reason for doing so.
} 
collecting their taxes than its own. Central governments are unlikely to have much incentive to do a good job. After all, it's not their money, and national political and other concerns seldom turn on the needs and concerns of lower levels of government. In the terms mentioned earlier, it may perhaps prove easier to remedy 'incompetence' than 'indifference.' Moreover, bringing administration closer to the people it is supposed to serve may result not only in improved accountability gains but also efficiency gains - and perhaps even increased revenues -- because people can more easily identify how fairly taxes are being administered and what the money is being spent on. Better local information and knowledge, more flexibility in organizing and staffing to fit local conditions, greater scope for innovation when there are several tax agencies rather than one monopoly, and above all the greater incentive for local administrators to collect and spend local revenues effectively may all make increased local control over tax administration a vital component of the kind of fiscal autonomy that seems most likely to produce the theoretical benefits of fiscal decentralization.

Some of the problems commonly associated with decentralizing tax administration can be overcome. For example, a standard lament is that local administrative capacity is inadequate to do the job properly. While this may sometimes be not only true but inescapable - for instance, small local governments are unlikely ever to be able to operate a standard credit-invoice VAT efficiently ${ }^{37}$-- there are many ways around this problem. As Sir Arthur Lewis (1967) noted long ago, too often those at the top seem to underestimate the potential of local administrators to do a good job. If better performance is valued and rewarded, and if pathways to improving capability and capacity are made available, there is no a priori reason to assume that people will not respond positively. As with fiscal decentralization in general, there is undoubtedly a learning curve: it may take time, perhaps quite a lot of time, for regional and local governments and their citizens to learn how to run things effectively, let alone efficiently, especially in countries in which subnational officials have little experience with such matters. But they can and do learn, and since better local tax administration will build additional capacity in financial administration the result may also be improved local financial management and better expenditure outcomes.

Additional costs associated with decentralized administration may thus to some extent be offset by benefits in terms of improved efficiency, equity, acceptability, and accountability. For example, although residential property taxes are not only unpopular but relatively costly to administer well, the higher costs may be fully justified both by the 'benefit tax' aspect of such taxes and by how they increase government accountability (Bird and Slack 2014). On the other hand, taxes -- whether property taxes, income taxes, or excise taxes -- imposed on local businesses that export most output (and hence most taxes unless they are, improbably, operating in a completely competitive market) to other jurisdictions are usually popular and may be imposed at lower costs per dollar of net revenue collected. Such taxes reduce not only accountability but also economic efficiency.

In some instances, decentralization may, instead of increasing competition between governments for a fixed amount of 'tax room', even increase the acceptable level of taxation. To the extent local

\footnotetext{
${ }^{37}$ Though, as Canada shows, regional governments can do so and, as a number of countries (Japan, Italy, France) have demonstrated even local governments can use a different type of VAT effectively (Bird 2015).
} 
administration may improve accountability by making it clearer to taxpayers what their taxes are buying, their willingness to pay may be increased (Mikesell 2007). Surveys in Colombia for example, suggest that citizens in all economic groups felt they were getting more out of paying taxes to local than to national governments (Acosta and Bird 2005). If local administrators do a better job of identifying and assessing the tax base, overall revenue mobilization may increase. In Armenia, for example, the delegation of property tax collection responsibility to the local government level in 2003-2005 reportedly led to a 38 percent increase in collected tax revenue. On the other hand, the centralization of sales tax administration in Kyrgyzstan in 2009 resulted in a decrease in the amount of collected tax (Golovanova and Kurlyandskaya 2011). In Peru, those municipalities that created autonomous local tax offices on average raised their own-source revenues by 81 percent from 1997 to 2008, compare to an increase of only 61 percent in those that did not. The locally-run offices were found to have improved in terms of less political interference, better client focus and more trust, less corruption, more innovation and, interestingly, also in better cooperation with other tax administrations (Fretes Ciblis and TerMinassian 2015).

Decentralized administration may also permit some new forms of taxation to be implemented. In many countries regional and local governments have broadened the tax net through a variety of special tax instruments and administrative measures such as levies on the sales of assets, licenses to operate, betterment charges and various forms of property and land taxation (Bird and Bird 2008). Bahl and Linn (1992) suggest that dividing tax bases according to comparative advantages in assessment and collection may broaden the tax base that can be effectively reached especially in the so-called "hard to tax" sector (Alm, Martinez-Vazquez and Wallace 2004). ${ }^{38}$ In developing countries state and local governments usually oversee a variety of licensing and regulatory activities and may be better able than the central government to track property ownership and land-based transactions as well as to identify local businesses and gain some knowledge about their assets and scale of operation. Because the potential revenue gains are much more important for local governments, they have more incentive to attempt to capture some who do not fully comply with national taxes or evade taxes altogether such as small businesses and the self-employed. ${ }^{39}$

However, even when there is a strong administrative case for a tax to be locally administered because of the comparative advantage of local governments in identifying the tax base because of their familiarity with local conditions, such tasks as valuing properties can be complex and require coordinated action between a number of different local, state, and national agencies and departments. The central (or state) government should often play a substantial role in such tasks as setting valuation standards, training valuers, and monitoring the quality of local assessments especially when, as is common, intergovernmental transfers are based to some extent on estimates of the potential local tax base. ${ }^{40}$ All

\footnotetext{
${ }^{38}$ Segmentation of tax bases in terms of both structure and administration is also suggested in a recent review of how to improve local government taxation in Africa (Fjeldstad, Chambas and Brun 2014)

${ }^{39}$ As noted in Section 3, however, this incentive may be offset by the disincentive created by inappropriately designed intergovernmental transfer systems. In this and other ways, central governments arguably get the local governments their own policies shape.

${ }^{40}$ See, for example, the discussions of valuation in Bird and Slack (2004) and of transfers in Bird and Smart (2002).
} 
too often, however, central valuation agencies have shown little willingness in practices to respond to local needs for support in improving and maintaining local taxing capacity.

The increasing 'informatization' of the world and the greatly expanded reliance on information technology (IT) to deal with routine administrative processes has been a two-edged sword when it comes to tax decentralization. On one hand, central tax administration can capture economies of scale through e.g. centralized EDP services and record-keeping, uniform approaches to assessment and audit, the development of centralized training programs, and so on (Vehorn and Ahmad 1997). On the other, IT can provide means to achieve more uniform service levels more efficiently and fairly in a more decentralized fashion without requiring every locality to have highly specialized skills. IT permits a country to multiply its available skills by making them available at a distance when required as well as to monitor outcomes more effectively (Bird and Zolt 2008). Such a system may, for instance, be one way to check the common concern about excessive corruption at the local government level, where the other side of being close enough to taxpayers to know them is being close enough to them to be susceptible to improper influences.

Technical and political factors, however, are sometimes binding constraints at the local level in developing countries. ${ }^{41}$ There is no costless way to address all the constraints binding local tax administrative capacity, but some tradeoffs are always possible. A common approach is to restrict state and local governments only to taxes that are considered to be most easily administered. For example, Mexico and Australia allow states to impose payroll taxes; Argentina and Canada let them impose certain types of sales taxes; many countries allow state and/or local governments to impose taxes on the ownership or use of motor vehicle licenses; and many permit state and local governments to impose some form of business licenses as well as property taxes. However, some of these 'easy-to-tax' taxes are all too often in practice poorly designed (most presumptive levies) or economically inefficient (property transfer taxes) or, like many property taxes, simply badly administered with low coverage rates, arbitrary assessment, and large delinquent lists.

Central governments are usually keen to control corporate taxes for revenue, stabilization, and regulatory purposes. Such taxes are also difficult for small governments to administer effectively, let alone efficiently. Taxes on international trade, like those on international investment flows, are also both difficult for regional and local governments to implement properly and highly distorting in efficiency terms. On the other hand, as North American experience shows, regional and even local sales taxes are possible, though since even national jurisdictions have so far been unable to tax some crossborder business activities fairly, efficiently and effectively they are even less likely to be able to do so (Bird 2015). Although it is easier for sub-national governments to tax personal incomes (as in Switzerland, the U.S., and the Nordic countries) or to impose payroll taxes (as in Australia and Mexico) than to tax corporations, central governments may again be reluctant to permit them to do so, for example, because maintaining a degree of visible progressivity in direct taxation may be considered necessary for political stability (Bird and Zolt 2015). The regulatory role of taxation may also play an important role in shaping a continued central role in excises on such products as alcohol, tobacco and

\footnotetext{
${ }^{41}$ For a good (or bad) example, see Enahoro and Olabisi (2012) on the state of Lagos, Nigeria.
} 
petroleum, even though such taxes have sometimes been suggested as more suitable for subnational governments (McLure 1997) and are extensively used by such governments in some countries.

Nonetheless, a possible comparative advantage for subnational government taxation relates to small taxpayers, who usually are less easily reached by central tax systems. Most tax revenue in most developing countries comes from a relatively small number of taxpayers. VAT, excises, corporate income tax and even most personal income tax are mainly collected from larger firms in the formal sector of the economy. ${ }^{42}$ Indeed, Keen and Mintz (2004) argue that the VAT threshold should be set at a relatively high level in terms of gross sales in order to exclude small taxpayers that it is not cost effective to reach. Similarly, the exemption level for the personal income tax in many developing countries is well above the average income level (Bird and Zolt 2005), and corporate income taxes often cover only large firms. However, local governments often impose various types of taxes and fees on small businesses excluded from the ambit of central taxes. The amounts of revenue raised through such levies are usually not large. Nonetheless, particularly in larger cities, these revenues are often both important and elastic and more use can and should be made of better-designed local business taxes (Bird 2006).

The policy constraints imposed on sub-national taxation may sometimes lead local governments to engage in a desperate search for revenues by piling on all sorts of specific local levies -- entertainment taxes, advertising taxes, business taxes, and so on - which are usually costly to collect and often arbitrary in their administration. At one point, for example, China eliminated a major local tax and then implicitly allowed local governments to create an array of ad hoc, piecemeal and sometimes clearly illicit ways of filling the revenue hole that had been created (Wong and Bird 2008; Bird et al. 2011). The outcome of pushing e.g. growing cities to rely on such a hodgepodge of revenue sources is unlikely to be equitable or efficient, let alone to encourage responsible accountability. One reaction is to impose still stricter constraints, as when Russia reduced the list of local taxes from 22 to two in 2005 (Golovanova and Kurlyandskaya 2011). It is easy to go too far in this direction. Making it difficult for local governments to tax local businesses may reduce administrative costs, compliance costs, and also distortion costs. But if the result is not only to weaken the link between local government and local businesses but also the incentive for local governments to favor investment and growth, the game may not be worth the candle.

A different approach to reducing the costs of collecting local revenue is by altering the structure of local taxed. One example is using area-based assessments for property taxation instead of more sophisticated valuation approaches based on comparative sales values (Slack 2006). Another is a business license based on the estimated volume of sales rather than a sales tax based on actual sales records. ${ }^{43}$ However, such shortcuts may make a tax easier to administer at the expense of making it a less effective tax in other ways - for example, in the property tax case just mentioned by moving it from being a tax on property value and hence reducing its potential role as a surrogate form of benefit taxation (Bird and Slack 2014)

\footnotetext{
${ }^{42}$ Of course, the incidence of many of these taxes may be spread much more evenly across the population.

${ }^{43}$ This is how the industry and commerce tax operates in Colombian municipalities (Vazquez-Caro and Ospina 2006).
} 
A better approach in many instances may thus be for regional and local governments to 'piggyback' on the tax base of the higher level governments, as Canadian provinces do with respect to most of their taxes, thus in principle allowing them to be fully politically accountable without having to take on the task of tax administration. Like every approach this one has some drawbacks. Accountability may be adversely affected because taxpayers no longer view the tax as local because it is centrally administered and collected so that if the central government decides to alter the tax base - for example, to favor a particular industry or sector, local taxes are similarly affected (Martinez-Vazquez and Timofeev, 2010). Although this effect may be offset - in Canada, for example, the central government is required to adjust intergovernmental transfers if its changes have a marked effect on provincial revenues and provinces may, if they wish, offset federal base changes by credits and surtaxes to a limited extent - the tax base is still essentially set at the central level and the lines of accountability are somewhat confused.

Another obvious, though seldom observed, approach is simply to strengthen the administrative infrastructure of subnational governments and particularly to support them while they accumulate over time the necessary on-the-job experience to do the job properly. It may take a long time. Rome was not built in a day, and its tax administration is no doubt still far from perfect. Still, it has long been one of the world's great cities, millions have managed to live there not too badly, and much has been done to improve matters over time. Even in very poor countries, it is sometimes possible to improve local administration substantially in a relatively short time if the right people do the right things. In Sierra Leone, for example, a recent careful analysis of why decentralization worked well in some municipalities and not so well in others points out the great importance of particular local characteristics such as history, social settings, and the will and capacity of specific political figures (Jibao and Prichard 2015). Reforming taxes and tax administration is never easy, but it can be done, and has been done in many instances in many countries at many times. However, it takes time, patience, and consistent support none of which is readily available in many parts of the world. In South Africa, for example, a major source of revenue at the time the post-apartheid government took power was a local tax (the Regional Services Council levy) that was so poorly structured that it was doomed to fail at some point. It did, with the result that it was then abandoned completely, removing a significant revenue source from local governments, although it could easily have been saved by some restructuring (Bahl and Solomon 2003). Despite numerous attempts it has not proved possible to reassemble this Humpty-Dumpty once it was pushed over the wall. South Africa's burgeoning cities thusl have no adequate revenue base to cope with their pressing spending needs (Steytler 2013). Impatience for success can be fatal to the success of any aspect of fiscal decentralization including tax administration. Central politicians and officials, like local voters, seem often to expect too much to work too well too soon - and then react too adversely when their unrealistic expectations are not met.

\section{Conclusion}

This paper assumes that three key points put forward by many previous authors are correct. The first is that for political decentralization to produce the gains promised by its advocates it must be accompanied by the right kind of fiscal decentralization. The second is that both theory and experience 
tell us that the right kind of fiscal decentralization is for state and local governments to be responsible for raising and spending their own resources at the margin so that changes in spending decided by local politicians and officials are financed by changes in taxes decided by those same people and are as transparent as possible to local citizens. The third point is that this goal may be largely achieved by the combination of a properly designed intergovernmental fiscal transfer system and allowing state and local governments to decide what tax rates they impose (even if only within a limited range on a limited set of taxes) as well as how to spend the revenue.

The case for decentralizing taxes neither requires nor is necessarily constrained by local tax administration. Tax decentralization and the decentralization of tax administration are related but separable decisions. The appropriate scope and nature of local administration of local taxes in any particular context can be determined only after careful consideration of the many, sometimes rather nebulous, facets of the issue discussed above. Different countries at different times have reached different conclusions about the appropriate way to mix and match the separable issues of decentralizing taxes and decentralizing their administration. No country may have it quite right when taking all the relevant factors into consideration, at least when viewed from outside. However, decisions on such matters in the real world are not made outside but inside specific countries, few involved in such decisions are likely to attach the same weights to all factors, and usually no one has the full story in mind when decisions are made. As with many questions of institutional design, there is no one size fits all correct answer in this complex world to either the question of the extent to which taxes should be decentralized or the question of whether such taxes should also be administered in a decentralized fashion. However, thinking through these two distinct questions separately can be a useful step towards achieving better outcomes.

\section{References}

Acosta, Olga Lucia and Richard Bird (2005) "The Dilemma of Decentralization in Colombia," in Bird, James Poterba and Joel Slemrod, eds, Fiscal Reform in Colombia: Problems and Prospects (Cambridge, MA: MIT Press), 247-86.

Alarie, Benjamin and Richard Bird (2011) "Tax Aspects of Canadian Fiscal Federalism," in Gianluigi Bizioli and Claudio Sacchetto, eds., Tax Aspects of Fiscal Federalism: A Comparative Analysis (Amsterdam: IBFD), 77-136.

Alm, James. Jorge Martinez-Vazquez, and Sally Wallace, eds. (2004) Taxing the Hard to Tax: Lessons from Theory and Practice (Amsterdam: Elsevier)

Ambrosanio, Flavia and Massimo Bordignon (2014) "Normative versus Positive Theories of Revenue Assignments in Federations," in Ehtisham Ahmad and Giorgio Brosio, eds., Handbook of Multilateral Finance (Cheltenham UK: Edward Elgar), 231-263 
Bahl, Roy and Richard Bird (2008) "Subnational Taxes in Developing Countries: The Way Forward," Public Budgeting \& Finance, 28 (4): 1-25.

Bahl, Roy and Johannes Linn (1992) Urban Public Finance in Developing Countries. New York: Oxford University Press.

Bahl, Roy and David Solomon (2003) "The Regional Service Council Levy" in Roy Bahl and Paul Smoke, eds., Restructuring Local Government Finance in Developing Countries: Lessons from South Africa, (Cheltenham UK: Edward Elgar), 127-172.

Baretti, Christian, Bernd Huber, and Karl Lichtblau (2002) "A Tax on Tax Revenue: The Incentive Effects of Equalizing Transfers: Evidence from Germany," International Tax and Public Finance, 9 (6): 631-649.

Bayenet, Benoît and Philippe de Bruycker (2007) "Belgium: A Unique Evolving Federalism," in Richard M. Bird and Robert D. Ebel, eds., Fiscal Fragmentation in Decentralized Countries: Subsidiarity, Solidarity and Aysmmetry (Cheltenham UK: Edward Elgar), 169-207.

Bednar, Jenna (2009) The Robust Federation: Principles of Design (Cambridge UK: Cambridge University Press).

Bell, David, David Eiser, and Klaus Beckmann, eds. (2014) The Economic Consequences of Scottish Independence (Hamburg), available at www.scotecon.org/book.html, accessed 20 November 2015).

Berg-Dick, Paul, Michel Carreau, Deanne Field and Mireille Éthier (2008) "Tax Coordination under the Canadian Tax System," in Núria Bosch and José M. Durán, eds., Fiscal Federalism and Political Decentralization (Cheltenham UK: Edward Elgar), 169-192.

Bird, Richard (2000) "Fiscal Decentralization and Competitive Governments," in Gianluigi Galeotti, Pierre Salmon, and Ronald Wintrobe, eds., Competition and Structure: The Political Economy of Collective Decisions (Cambridge UK: Cambridge University Press, 2000), 129-49.

Bird, Richard (2006) "Local and Regional Revenues: Realities and Prospects," in Richard Bird and Francois Vaillancourt, eds., Perspectives on Fiscal Federalism. WBI Learning Resources Series (Washington, DC: World Bank), 177-96

Bird, Richard (2014) "The GST/HST: Creating an Integrated Sales Tax in a Federal Country" in Jack Mintz and Stephen Richardson, eds., After Twenty Years: The Future of the Goods and Services Tax (Toronto: Canadian Tax Foundation), 1-50.

Bird, Richard (2015) "Below the Salt: Decentralizing Value-Added Taxes," in Ehtisham Ahmad and Giorgio Brosio, eds., Handbook of Multilateral Finance (Cheltenham UK: Edward Elgar, 2015), 291-333.

Bird, Richard, Loren Brandt, Scott Rozelle, and Linxiu Zhang (2011) "Fiscal Reform and Rural Public Finance in China," in Joyce Yangyn Man and Yu-Hung Hong, eds., China's Local Public Finance in Transition (Cambridge, MA: Lincoln Institute for Land Policy), 227-243.

Bird, Richard and Pierre-Pascal Gendron (2010) "Sales Taxes in Canada: The GST-HST-QST-RST 'System,'” Tax Law Review, 63 (3): 517-582. 
Bird, Richard and Enid Slack (2004) International Handbook of Land and Property Taxation (Cheltenham, UK: Edward Elgar)

Bird, Richard and Enid Slack (2014) "Local Taxes and Local Expenditures in Developing Countries:

Strengthening the Wicksellian Connection," Public Administration and Development 34 (4): 359-369.

Bird, Richard, Enid Slack and Almos Tassonyi (2012) A Tale of Two Taxes: Reforming the Property Tax in Ontario. (Cambridge, MA: Lincoln Institute of Land Policy).

Bird, Richard and Michael Smart (2002) "Intergovernmental Fiscal Transfers: International Lessons for Developing Countries," World Development, 30 (6): 899-912.

Bird, Richard and Michael Smart (2010) "Assigning State Taxes in a Federal Country: The Case of Australia," in Melbourne Institute, Australia's Future Tax and Transfer Policy Conference (Melbourne: Melbourne Institute of Applied Economic and Social Research), 72-94.

Bird, Richard and Francois Vaillancourt (2006) "Changing With the Times: Success, Failure and Inertia in Canadian Federal Arrangements, 1945-2002," in Jessica Wallack and T.N. Srinivasan, eds., Federalism and Economic Reform: International Perspectives (Cambridge UK: Cambridge University Press), 189-248

Bird, Richard and Eric Zolt (2005) "Redistribution via Taxation: The Limited Role of the Personal Income Tax in Developing Countries," UCLA Law Review, 52 (6, 2005): 1627-95.

Bird, Richard and Eric Zolt (2008) "Technology and Taxation in Developing Countries: From Hand to Mouse," National Tax Journal, 61 (4. Part 2: 791-821.

Bird, Richard and Eric Zolt (2015) "Fiscal Contracting in Latin America," World Development, 67 (March): 323-335.

Blöchinger, Hansjörg and David King (2006) "Less than You Thought: The Fiscal Autonomy of Sub-Central Governments," OECD Economic Studies, 43: 155-188.

Bönke, Timm, Beate Jochimsen and Carsten Schröder (2013) Fiscal Federalism and Tax Administration: Evidence from Germany," Discussion Paper 1307, DIW Berlin,

Canada Department of Finance (2000) Federal Administration of Provincial Taxes: New Directions. (Ottawa).

Canada Revenue Agency (2014) Annual Report to Parliament 2013-2014 (available at http://www.craarc.gc.ca/gncy/nnnl/2013-2014/fn-dmnstrd-tvts-eng.html, accessed 20 November 2015).

Casanegra de Jantscher, Milka (1990) "Administering a VAT," in Malcolm Gillis, Carl Shoup, and Gerardo Sicat, eds., Value Added Taxation in Developing Countries. (Washington DC: World Bank).

Castells, Antoni (2001) "The Role of Intergovernmental Finance in Achieving Diversity and Cohesion: The Case of Spain," Environment and Policy C: Government and Policy, 19 (2): 189-206. 
CIAT-IDB (2012) State of the Tax Administration in Latin America, 2006-2010, available at http://www.ciat.org/index.php/en/products-and-services/publications/books/2539-estado-de-laadministracion-tributaria-en-america-latina-2006-2010.html, accessed 20 November 2015.

Cnossen, Sjibren (2010) "Commentary," in Mirrlees, James et al., Dimensions of Tax Design: the Mirrlees Review (Oxford UK: Oxford University Press), 370-386.

Cui, Wei (2011) “Fiscal Federalism in Chinese Taxation," World Tax Journal, October, 455-480.

Cui, Wei (2015) “Administrative Decentralization and Tax Compliance: A Transactional Cost Perspective," University of Toronto Law Journal, 65 (3): 186-238.

Dillinger, William (1991) Urban Property Tax Reform (Washington DC: World Bank).

Drenkard, Scott (2014) State and Local Sales Tax Rates in 2014 (http://taxfoundation.org/article/stateand-local-sales-tax-rates-2014, accessed 20 November 2015).

Durán-Cabre, José Maria, Alejandro Esteller-Moré, and Luca Salvadori (2012) Regional Competition on Tax Administration, Universitat de Barcelona \& Institut d'Economia de Barcelona, available as https://ideas.repec.org/p/wiw/wiwrsa/ersa12p184.html, accessed 20 November 2015.

Duran-Cabre, Jose Maria, Alejandro Esteller-More, and Luca Salvadori (2015) Empirical Evidence of Tax Cooperation between Sub-central Regions, Document de treball de l'IEB 2015/7, available at https://www.academia.edu/1567090/Empirical evidence on horizontal competition in tax enforcem ent, accessed 20 November 2015.

Enahoro, John A. and Jayeola Olabisi (2012) "Tax Administration and Revenue Generation of Lagos State Government, Nigeria," Research Journal of Finance and Accounting, 3 (5): 132-139.

Esteller Moré, Alejandro (2008) “Current Situation and Proposals for Reform of Spain's Tax Administration," in Núria Bosch and José Durán, eds., Fiscal Federalism and Political Decentralization (Cheltenham UK: Edward Elgar), 209-247.

Faguet, Jean-Paul and Caroline Pöschl (2015) Is Decentralization Good for Development? Perspectives from Academics and Policy Makers (Oxford: Oxford University Press).

Farber, Gisela, Marco Salm, and Stephanie Hengstwerth (2015) "Property Tax Reform in Germany: Eternally Unfinished?" in Junghun Kim, Jorgen Løtz and Niels Jørgen Mau, eds., Interaction between Local Expenditure Responsibilities and Local Tax Policy (Korea Institute of Public Finance and Danish Ministry for Economic Affairs and the Interior), 167-201.

Fjeldstad, Odd-Helge, Gerard Chambas, and jean-Francois Brun (2014) Local Government Taxation in Sub-Saharan Africa: A Review and an Agenda for Research, CMI Working Paper 2014:2.

Fretes Cibils, Vicente and Teresa Ter-Minassian, eds. (2015) Decentralizing Revenue in Latin America: Why and How (Washington: Inter-American Development Bank). 
Garcia-Milà, Teresa, and Therese J. McGuire (2007) "Fiscal Decentralization in Spain: An Asymmetric Transition to Democracy," in in Richard Bird and Robert Ebel, eds., Fiscal Fragmentation in Decentralized Countries: Subsidiarity, Solidarity and Asymmetry (Cheltenham UK: Edward Elgar), 208-223.

Golanova, Natalia, and Galina Kuryandskaya (2011) “Local Public Finances in Eurasia," in Local Government and Finance: The Challenges of the 21st Century. Second Global Report on Decentralization and Local Democracy. (Cheltenham UK: Edward Elgar) pp.117-152

Gray, Caroline (2015) “A Fiscal Path to Sovereignty? The Basque Economic Agreement and Nationalist Politics," Nationalism and Ethnic Politics, 21 (5): 63-82.

Hőgye, Mihály, ed.,(2000) Local and Regional Tax Administration in Transition Countries (Budapest: Local Government Public Service Reform Initiative).

Jibao, Samuel S. and Wilson Prichard (2015) "The Political Economy of Property Tax in Africa: Explaining Reform Outcomes in Sierra Leone," African Affairs, 114 (456): 404-431.

Joshi, Anuradha, Wilson Prichard and Christopher Heady (2014) "Taxing the Informal Sector: The Current State of Knowledge and Agendas for Future Research," Journal of Development Studies, 50 (10): 13251347.

Keen, Michael, and Jack Mintz (2004) "The Optimal Threshold for a Value-added Tax," Journal of Public Economics, 88: 559-76.

Lewis, Arthur (1967) “Planning Public Expenditure," in Max Millikan, ed., National Economic Planning (New York: Columbia University Press), 210-227.

Lewis, Blane (2006) "Local Government Taxation: An Analysis of Administrative Cost Inefficiency," Bulletin of Indonesian Studies, 42 (2): 213-233.

Lopez-Laborda, Julio, and Carlos Monsterio Escudero (2007) "Regional Governments: Vertical Imbalances and Revenue Assignments," in Jorge Martinez-Vazquez and Jose Felix Sanz-Sanz, eds., Fiscal Reform in Spain: Accomplishments and Challenges (Cheltenham UK: Edward Elgar), 422-452.

Løtz, Jorgen, Jens Blom-Hansen and Søren Hartmann Hede (2015) "The Changing Role of Local Income Taxation in Denmark," in Junghun Kim, Jorgen Løtz and Niels Jørgen Mau, eds., Interaction between Local Expenditure Responsibilities and Local Tax Policy (Korea Institute of Public Finance and Danish Ministry for Economic Affairs and the Interior), 231-251.

Martinez-Vazquez, Jorge and Jes Felix Sanz-Sanz, eds. (2007) Fiscal Reform in Spain: Accomplishments and Challenges (Cheltenham UK: Edward Elgar).

Martinez Vazquez, Jorge, Charles McLure and Francois Vaillancourt (2006) "Revenues and Expenditures in an Intergovernmental Framework," in Richard Bird and Francois Vaillancourt eds, Perspectives on Fiscal Federalism. WBI Learning Resources Series (Washington, DC: World Bank), 15-34. 
Martinez-Vazquez, Jorge, and Andrey Timofeev (2010). "Choosing between Centralized and Decentralized Models of Tax Administration" International Journal of Public Administration, 33 (12-13): 601-619.

McLure, Charles (1997) "Topics in the Theory of Revenue Assignment: Gaps, Traps, and Nuances," in Mario Blejer and Teresa Ter-Minassian, eds., Macroeconomic Dimensions of Public Finance (London: Routledge), 94-109.

McLure, Charles (2000). "Tax Assignment and Subnational Fiscal Autonomy" Bulletin for International Fiscal Documentation (December): 626-635.

Mikesell, John (2007). "Developing Options for the Administration of Local Taxes: An International Review" Public Budgeting \& Finance, 27 (1): 41-68.

Moya, Rafael Moya and José-Damián Santiago (1992) "Information Technology: Strategy of the Spanish Tax Administration," in Richard M. Bird and Milka Casanegra de Jantscher, eds., Improving Tax Administration in Developing Countries (Washington DC: International Monetary Fund), 211-235.

Nault, Philippe (2006) Tax Administration in a Decentralized Tax System: A Canadian Perspective, November, available at www.ief.es/.../internacional/Sem Inter Tax PhilipNault TaxAd.pdf, accessed 10 November 2015).

Oates, Wallace (1972) Fiscal Federalism (New York: Harcourt Brace Jovanovich).

OECD (2015) Comparative Tax Administration 2015 (Paris).

Onrubia, Jorge (2007) "The Reform of the Tax Administration in Spain," in Jorge Martinez-Vazquez and Jose Felix Sanz-Sanz, eds., Fiscal Reform in Spain: Accomplishments and Challenges (Cheltenham UK: Edward Elgar), 484-531.

Piffano, Horacio (2005) “Fiscal Decentralization, Tax Competition, and Federal Tax Administration: A Note from the Argentine Experience," Revista de Economía y Estadística (Córdoba), 43: 7-28.

Plamondon, Robert, and David Zussman (1998). "The Compliance Costs of Canada's Major Tax Systems and the Impact of Single Administration," Canadian Tax Journal, 46 (4): 761-785.

Ruiz Almendral, Violeta (2012) "Sharing Taxes and Sharing the Deficit in Spanish Fiscal Federalism," eJournal of Tax Research, 10 (1): 88-125.

Slack, Enid (2006). "Alternative Approaches to Taxing Land and Property," in Richard Bird and Francois Vaillancourt, eds., Perspectives on Fiscal Federalism. WBI Learning Resources Series (Washington, DC: World Bank), 197-223.

Slack, Enid and Richard Bird (2014) The Political Economy of Property Tax Reform, OECD Working Papers on Fiscal Federalism No. 18, OECD Publishing, Paris, April.

Slemrod, Joel and Christian Gillitzer (2014) Tax Systems (Cambridge MA: The MIT Press). 
Smart, Michael (1998) "Taxation and Deadweight Loss in a System with Intergovernmental Transfers," Canadian Journal of Economics, 31 (1): 189-206.

Smith, Ernest H. (1998) Federal-Provincial Tax Sharing and Centralized Tax Collection in Canada (Toronto: Canadian Tax Foundation).

Steytler, Nico (2013) "Governance and Finance in Two South Africa Metropolitan Areas," In Enid Slack and Rupak Chattopadhyay, eds., Governance and Finance in Metropolitan Areas of Federal Systems (Oxford UK: Oxford University Press),

Swianiewicz, Pawel and Julita Łukomska (2015) "Local Tax Policies in the Limited Autonomy of the revenue Collection System in Poland," in Junghun Kim, Jorgen Løtz and Niels Jørgen Mau, eds., Interaction between Local Expenditure Responsibilities and Local Tax Policy (Korea Institute of Public Finance and Danish Ministry for Economic Affairs and the Interior), 255-280.

Ulbricht, Alexander (2008) "The Decentralization of Tax Administration in Germany: Consequences," in in Núria Bosch and José M. Durán, eds., Fiscal Federalism and Political Decentralization (Cheltenham UK: Edward Elgar), 193-208.

Vázquez Caro, Jaime and José Abelino Ospina (2006) “Evaluación sistémica de la ley impositiva colombiana," in Juan José Echavarría, ed., Bases para una reforma tributaria estructural en Colombia (Bogotá: Fedesarrollo y Banco de la República), 385-507.

Vehorn, Charles L. and Ehtisham Ahmad (1997). "Tax Administration," in Teresa Ter-Minassian, ed., Fiscal Federalism in Theory and Practice. Washington: International Monetary Fund.

Velasco, José Luis (2008) Servicio de Administractión Tributaria de México, Working Paper 08-15, Center for Migration and Development, Princeton University, September (www.princeton.edu/cmd/workingpapers/idlac08/wp0805k.pdf, accessed 18 November 2015).

Weingast, Barry (2009) "Second-Generation Fiscal Federalism," Journal of Urban Economics, 65: 279293.

Wong, Christine and Richard Bird (2008) "China's Fiscal System: A Work in Progress," in Loren Brandt and Thomas G. Rawski, eds., China's Great Transformation: Origins, Mechanisms, and Consequences of the Post-Reform Economic Boom, (Cambridge: Cambridge University Press), pp. 429-66. 